\title{
Territorialization of the REDD + strategy in the Bribri indigenous people, Talamanca, Costa Rica
}

\author{
Maritza Marín-Herrera \\ Heidy Correa-Correa \\ Gustavo Blanco-Wells
}

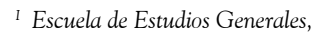
Universidad de Costa Rica, San José, Costa Rica.

"I Escuela de Graduados, Facultad de Ciencias Económicas y Administrativas, Universidad Austral de Chile.

III Instituto de Historia y Ciencias Sociales de la Universidad Austral de Chile. Centro de Ciencias del Clima y la Resiliencia, Chile
Abstract: This article explores how the attempt of implementing REDD + affects the livelihoods and nature valuation of the Bribri indigenous people in Talamanca, Costa Rica. The analysis is done using a case study, discourse analysis and collective hermeneutics in documents and interviews produced by international, national, and local social actors. Controversies in the REDD+ strategy have been manifested in the initiative's de/re/territorialization processes. These processes are legitimized by technocratic discursive strategies associated with climate change mitigation, produced in multilateral negotiations, and adapted by national institutions for purposes not aligned with the interests of the communities. It is concluded that the implementation of REDD + in indigenous territories in Costa Rica gives way to i) the commoditization of nature, participation and traditional forms of governance; ii) the consolidation of a climate eco-governmentality based on the fragmentation of nature; iii) building representations of vulnerable and impoverished indigenous people, and thus justifying intervention in their territories.

Keywords: Territorialization, Climate Eco-governmentality, Native people, Payment for Ecosystem Services.

São Paulo. Vol. 24, 2021

Original Article

DOI: http://dx.doi.org/10.1590/1809-4422asoc20180231r2vu2021L1AO 


\section{Introduction}

The strategy for the Reduction of Emissions from Deforestation and Degradation of forests (REDD*) is an international mechanism whose objective is the mitigation of Green House Gases (GHG). Its point of reference in that tropical forests constitute $41 \%$ of the world total, their deforestation produces $25 \%$ of GHG emissions (HOUGHTON, 2005, ERA VERDE, 2014), making them the second most significant cause of said emissions. They are home to 50 and $90 \%$ of the world's species and the means for material and cultural subsistence of local communities.

The implementation of REDD+ has become a controversial subject for indigenous peoples of Latin America, Asia, and Africa (PETKOBA Y LARSON, 2011, MOVIMIENTO MUNDIAL POR LOS BOSQUES TROPICALES, 2015) since it is loaded with uncertainties and mediated by multiple latent or manifest interests. In Latin America, forests are found mainly in indigenous territories (DAM, 2011), which is why governments have a special interest in including them as beneficiaries of REDD+ policies and incentives with the intention of explicitly guaranteeing $\mathrm{CO}_{2}$ sinks.

Costa Rica has become an international reference for the adoption of policies related to climate change. The Payment for Environmental Services (PES) as a predecessor to REDD + has been executed since 1996 with the participation, among other beneficiaries, of different indigenous communities located in Costa Rican national territory. From 1997 to 2018 there have been 284 contracts involving indigenous territory, representing 1,6\% of the total contracts, for a total sum of 5,414,169.30 USD (FONAFIFO, 2019a, 2019b). However, the indigenous communities included in this study, with the support of organizations and social movements, report a lack of information about the implementation of $\mathrm{REDD}+$, as well as important changes in their way of life as the strategy is consolidated (MENDEZ, 2014a).

The case of the Talamanca-Bribri was selected due to their record of resistance before pressure from national and transnational corporations interested in using the natural resources in their territories (MENDEZ, 2014b). Bribri land has ample forest covering, appropriate for REDD+ strategy incentives, but indigenous Bribri leaders disagree on its implementation and question the payment of incentives for the conservation of forests in places that have a productive culture allowing for respectful coexistence with nature (MENDEZ, 2014a).

We explore the possible implications of REDD + in the appreciation of nature and Bribri ways of life, from the view of international, national, and local actors in the processes of des/re/territorialization of the REDD+ initiative. Particularly, the article delves into and presents practices associated with the translation of discourses on climate change in Costa Rica, the discourse of the Bribri people about REDD + , and its incidence on other levels of Extra-territorial decisions, recognizing that interactions between scales are not linear and that, therefore, it may be a two way process.

First, the theoretical-methodology section includes conceptual tools and strategies used for the information analysis. Then, the case is described globally, nationally, and locally, as are its policies, programs, representations, and practices, on the one hand, for 
national and international institutionality, and on the other, for the Bribri community. Finally, the process of de/territorialization in the area of governance is analyzed, considering the relation between policies and the political, the epistemological dimensions, and productive practices.

\section{Theories and Methods.}

\section{Territorialization/deterritorialization and policies of climatic eco-governmentality}

The study of international policies on climate change and the politics that sustain them require an understanding of the complex scheme of their construction and implementation, from their gestation in the transnational arena to their process of translation to local levels (BLANCO, 2016). Equally relevant is understanding the inverse processes, in other words, creative actions of existence or resistance that are built from social spaces that we identify as local and whose influence can escalate towards places we associate with the global.

The approach to global climate change cannot be exclusively understood through techno-scientific discourses. Through institutions, expert knowledge, and specialized language, the implementation of supranational policies is legitimized before the international community, seeking to mitigate environmental damage and global affectation. In that epistemic and political movement of climate expertise, geopolitics of knowledge are produced that are examined due to their consequences in other spaces and territories (ULLOA, 2011). Climate change, as defined by techno-political global actors, reconfigures social relations and concrete material relations on a local, national, and transnational level, consolidating what Astrid Ulloa, who was inspired by the ideas of Foucault, calls climate eco-governmentality (ULLOA, 2011). This eco-governmentality implies a specific rationale, based on the will to govern processes linked to the environment under a technocratic reasoning with universalist principles, mainly based on market solutions. Nature and its services become tradable goods, susceptible to fragmentation for their commercialization in the international market.

The process of translating and making directives, concepts, agreements, and norms generated in the international area materially significative, with deliberate objectives of transforming territories and localities, is part of the actions we identify with climatic ecogovernmentality. This operates, as do other expansive and multisituated processes, with a double movement of territorialization and deterritorialization constituting true assemblages by their action. (DE LANDA, 2006, 2016). Territorialization implies heterogeneous entities (social or material) linked by relations and/or flows to a specific geographic space that experiment processes of relative homogenization, identity, and cohesion generating movements (DE LANDA, 2016, ANDERSON AND MACFARLANE, 2011). These processes are not necessarily stable or permanent; on the contrary, deterritorialization moves inversely, eliminating internal consistency and partially destabilizing territorial entities, disarticulating their relations or reconfiguring them. Discourses, in turn, are 
territorialized from spaces identified with the global towards others we associate with the local, suffering transformations -re-territorialization or de-territorialization-inversely, from the local to the global (DE LANDA, 2016, ANDERSON AND MACFARLANE, 2011) In the case of indigenous communities, deterritorialization also implies the decoupling of forms of governance and epistemology. The processes of territorialization/deterritorialization position indigenous communities in new contexts of struggle for their territories (ULLOA, 2011).

Relational dynamics among indigenous communities, national, and transnational entities develop on the basis of the autonomy of peoples, endorsed by the ILO Convention 169 and the Declaration of the United Nations on the Rights of Indigenous Peoples. The exercise of autonomy upon territories is limited in the face of national and supra national policies, conditioning their capacity for negotiation, confrontation, and participation in positioning their demands, frequently recurring to the same globalizing policies. Ulloa calls this process relational autonomy (ULLOA, 2011).).

Through relational autonomy indigenous people may, potentially, generate spaces and networks to position their discourses and demands with local, national, and transnational actors, in such a manner that territorialization may occur, as we have stated, from the local to the global in a two-way process.

The subject matter of this work, therefore, is the effects of the REDD+ mechanism, analyzed by representation, discourse, policies, programs, and practices linked to the intended implementation among the indigenous Bribri in Talamanca, Costa Rica. The relevance of the territorial unit of analysis abides in that, first, Costa Rica is characterized by being a country at the vanguard of environmental policies; second, in that among the Bribri community there are dissimilar points of view as to their participation in the REDD+ mechanism.

\section{Methodology}

The work is organized as a case study, using ideological discourse analysis. According van Dijk (1996), this type of analysis allows comparing discursive structures with social practices, identifying sociopolitical ideologies or cognitions associated with each social actor's standing, such as means of persuasion present in their discourses. For the purposes of this investigation, positive and negative qualifications of social actors' language were examined, in reference to themselves (ingroups) and others (outgroups).

Considering that each social actor builds their discourse according to their situationality and ideological standing, those positions are identified in the texts, following the topics proposed by van Dijk (1996), in other words, descriptions of self-identity, activity, purpose, norms and value, position and relation, and lastly resources. These topics were applied to the corpus analysis (see CHART 1) under the organization of units of analysis as detailed: 
- international and national policies on climate change,

- REDD+ as a specific policy,

- the Bribri community and,

- Bribri community jungle territory, expressions related to:

- Modes of knowing

- Modes of governing

- Modes of producing

The articulating concepts of these four units of analysis are: the movement between territorialization/de-territorialization (ANDERSON AND MACFARLANE, 2011) and climatic eco-governmentality (ULLOA,2011).

In order to achieve a more profound interpretation of this data, four sessions of collective hermeneutics took place (MOLITOR, 2001), consisting of the confrontation of the individual reading of each author, in order to agree upon a collective interpretation of the stance of the analyzed documents, recognizing their manifest meaning and latent expressions.

For the corpus selection source, accessibility and reliability criteria were used. The discursive corpus was composed of three documental groups (see chart 1):

a) Official web sites: el Fondo Nacional de Financiamiento Forestal (FONAFIFONational Forestry Finance Fund); UN-REDD Costa Rica on social media; videos of open forums with government participation.

b) Audios and videos published on social media from 2007 (beginning of REDD+ proposal) and 2016 (reaction to the Conference of Parties-21) produced by: Kioskos Socio-Ambientales and Era Verde, institutional programs of the Universidad de Costa Rica.

c) Four reports generated by the FONAFIFO-MINAE about PES.

d) Additionally, and as a means of triangulation, there were also a semi-structured interview with a Bribri indigenous leader and an interview with a FONAFIFO consultor. 


\section{Chart 1. Detailed list of the corpus of analysis}

\begin{tabular}{|c|c|}
\hline Corpus & Description \\
\hline $\begin{array}{l}2 \text { Era Verde television pro- } \\
\text { grams }\end{array}$ & $\begin{array}{l}\text { Two 24- and 29-minute programs interviewing: Leonardo } \\
\text { Buitrago, Bribri leader; Mariana Porras of the Coecoceiba } \\
\text { Organization; Baudilio Selles and Jhonny Buitrago of the Ta- } \\
\text { lamanca Bribri, as well as informative capsules about REDD+ } \\
\text { mechanism. }\end{array}$ \\
\hline 1 Video of Caravana Climática & $\begin{array}{l}2 \text { min } 15 \text { s video with statements of ex-leader Baldomero Waisa } \\
\text { Pereira, indigenous Bribri, REDD+ on indigenous representa- } \\
\text { tion on subjects relating to REDD+. }\end{array}$ \\
\hline 1 Caravana Climática audio & $\begin{array}{l}7 \text { min } 49 \text { s video of statements from Leonardo Buitrago, indig- } \\
\text { enous Bribri leader and member of ADITIBRI (Asociación de } \\
\text { Desarrollo Integral del Territorio Indígena Bribri -Association } \\
\text { of Integrated Development of Indigenous Bribri Territory-), } \\
\text { referring to the history of payment for environmental services } \\
\text { in the territory. }\end{array}$ \\
\hline $\begin{array}{l}1 \text { video from Kioskos Socio- } \\
\text { ambientales }\end{array}$ & $\begin{array}{l}\text { Presents 12-minute audio with photo of meeting between Bribri } \\
\text { community of the South Caribbean and members of the Ministry } \\
\text { of Environment and Energy of Costa Rica. }\end{array}$ \\
\hline $\begin{array}{l}3 \text { official Government of Costa } \\
\text { Rica websites }\end{array}$ & $\begin{array}{l}\text { These three pages were available between } 2015 \text { and } 2016 \text { with } \\
\text { official information on REDD+: } \\
\text { http://www.fonafifo.go.cr } \\
\text { http://www.cambioclimaticocr.com } \\
\text { http://reddcr.go.cr }\end{array}$ \\
\hline $\begin{array}{l}1 \text { interview with Bribri and } 1 \\
\text { interview with FONAFIFO } \\
\text { consultor. }\end{array}$ & $\begin{array}{l}\text { The interviews took place in October } 2015 \text {. They were semi- } \\
\text { structured and covered two main subjects: the significance } \\
\text { and use of forests for the Bribri people and representativity } \\
\text { and decision making (consulting process, role of international, } \\
\text { national, and local indigenous organizations). The documental } \\
\text { corpus was contrasted by triangulation perspective through } \\
\text { these semi/structured interviews. }\end{array}$ \\
\hline
\end{tabular}

Source: Authors.

It is worth noting, that being a case study, the results of this work are not meant to be generalized to their populations, but rather, to obtain an understanding about social processes of public interest. Recording dynamic accelerated processes, such as those explored in this text, surpasses the capacity to document them in their entirety; therefore, a case study is a partial approximation to the phenomenon at a given moment. 


\section{The politics surrounding climate change and REDD+}

REDD + arose from an initiative presented by the Costa Rican government through the Ministry of Environment and Energy and the Papua New Guinea government (CULAS, 2012), during COP11 in Montreal in 2005, but it came into being in 2007 at COP13 in Bali. It was proposed as a mechanism for the reduction of emissions caused by the indiscriminate exploitation of tropical forests in developing countries. The SBSTA (Subsidiary Body for Scientific and Technological Advice), generated a proposal called REDD+, an acronym referring to the Reduction of Emissions from Deforestation and Degradation of forests, conservation, sustainable management, and improvement of forest carbon stock.

This policy is directed towards non-industrialized countries, tropical and sub-tropical, that receive funds, channeled through the FCPF (Forest Carbon Partnership Facility) of the World Bank and the UN-REDD, financed through commitments of industrialized countries to mitigate emissions of GHG (FOREST CARBON PARTNERSHIP FACILITY, 2017). Culas (2012) defines this policy as "(...)north-south financial transference to compensate sacrificed income and also for the costs associated with monitoring and controlling the exploitation of the forests, such as curbing corruption and illegal felling by local and foreign corporations".

REDD +, meanwhile, positions industrialized countries as agents, who by positive channeling of economic resources contribute to the international economy in two ways: a) by supporting the mitigation of GHG; b) mitigating poverty in developing or poor countries.

Since the presentation of the proposal in 2005, during the annual COP, different aspects of the REDD + mechanism have been discussed, which build a technocratic narrative based on the enunciation of the same policies, for example:

- Between 2006 and 2010, the reach and strategies for Measuring, Registering, and Verification (MRV) of emissions from deforestation were debated: funding, institutional agreements, and the rights of indigenous peoples. The importance of the other (indigenous) as relevant actors in the implementation of the mechanism was recognized (FOREST CARBON PARTNERSHIP FACILITY, 2017).

- At COP18 in Cancun-2010, safeguards for the rights of indigenous peoples were put into place as well as the preservation of natural forests. Respect for national sovereignty and funding from developed countries was emphasized.

- COP19 in2013 in Warsaw provided a guide on how to create snapshots of forests though time, and how to use them for creating levels of reference of deforestation that can be recognized by the United Nations Framework Convention on Climate Change (UNFCC) (FOREST CARBON PARTNERSHIP FACILITY, 2017). Elements for funding REDD+ were also established. The technical language that legitimized REDD + negotiators and experts as actors with decision-making capacity was consolidated before people who did not possess such capacities. 
- At COP21 in Paris 2015, the implementation of non-monetary alternative methodologies, with a mitigation and joint adaptation plan that includes the management of collective resources and sustainable use of forests was promoted by Bolivia. However, they were not able to establish financing mechanisms that would grant the proposal's sustainability (19). Funding became the power tool capable of discriminating among the alternatives proposed by "beneficiaries" of the mechanism.

- At COP 23 in Bonn, Germany, the future of REDD+, its funding challenges, results-based implementation mechanisms, and the need for convergence in regard to a common, credible, and relevant accounting system were discussed. Thus, a narrative of supervision and control over the others was established.

\section{Politics in Costa Rica}

The country implemented a constitutional reform that guarantees the right to a healthy and ecologically balanced environment; the revision of the forestry law that recognizes biodiversity, water sources, scenic beauty, and carbon capture as ecosystem services; the ratification of international conventions such as the Kyoto Protocol (KP); and the commitment to be a carbon neutral country by 2021. This last commitment is the reason the 2009 National Strategy for Climate Change (ENCC- in Spanish) was formulated. Among its strategic aims was the mitigation of GHG, framed within international agreements such as Mechanisms for Clean Development (MCD), the NAMAS (National Appropriate Mitigation Actions), and the REDD+ program (MILLA, 2011).

With these proposals, Costa Rica-internationally recognized as a conservation and environmental protection pioneer- prepared to begin a third generation of actions for controlling deforestation as part of a process of forestry transition that reached its lowest point in 1987, with a forest covering of 21\% (MILLA, 2011).

REDD+ follows the PES scheme (MAHANTY AND TACCONI, 2013), consisting of a voluntary transaction, where land use assures an environmental service. The environmental service is bought by a supplier, if and when the supplier assures its provision (WUNDER, 2015).

Costa Rica began its participation in the REDD+ program in 2008, through the FONAFIFO and the Forest Carbon Partnership fund (FCPF). In 2010, the Readiness document was approved and went on to the implementation stage of REDD+, which implied preliminary consultation, particularly where indigenous territory was concerned (MAHANTY AND TACCONI, 2013).

According to the official FONAFIFO page, by implementing the REDD+ strategy, 341,000 hectares of private and indigenous land would be incorporated, capturing approximately 30 million tons of $\mathrm{CO}_{2}$ (FONAFIFO, 2014). These projections would contribute to maintaining the country's positive position in the international arena and attract foreign investment to the Voluntary Domestic Carbon Market (VDCM). The institutional objectives seek the preservation of nature while dynamizing the economy 
with, according to FONAFIFO, positive implications for different actors.

In 2013, the Costa Rican government signed a letter of intent with the FCPF, where it presented the intention of the FCPF to buy Costa Rican bonds for up to US $\$ 630$ million as long as Costa Rica complies with the agreed requirements. That same year the VDMCC was put into place where, contrary to the PES, the private sector could also generate and trade carbon bonds (DIRECCION CAMBIO CLIMATICO COSTA RICA, 2016). In this manner the Costa Rican government presented the carbon market as an activity within the reach of diverse economic groups.

\section{Bribri population and their jungle territory}

The territory of the indigenous Talamanca-Bribri is located in south-eastern Costa Rica between the Telire and Bratsi districts, where the Cabécar people and territory can also be found (Figure 1).

According to the 2011 National Census, the Talamanca-Bribri concentrate the majority of the indigenous population, representing $17.3 \%$ of the national total, with 7,757 people (INSTITUTO NACIONAL DE ESTADISTICA Y CENSO, 2013). The territories extension is 44 thousand hectares and was confirmed as an indigenous reserve by law N 6.172 in 1977 (FONAFIFO, 2013). According to the Fund for the First Trade of Debt for Nature U.S.A.-Costa Rica, this area possesses over 50\% of Costa Rica's fresh water supply and almost $70 \%$ of its forest cover (FONDO DEL PRIMER CANJE DE DEUDA POR NATURALEZA EEUU-C.R., 2013).

It is a territory that is rich in mineral resources, causing the Bribri to be in constant struggle to protect it. Their resistance ranges from maintaining their language, forms of political organization, economy, religion, and education to defending nature from private and government corporations (MENDEZ 2014b). 
Figure 1. Map of Bribri territory forest covering.

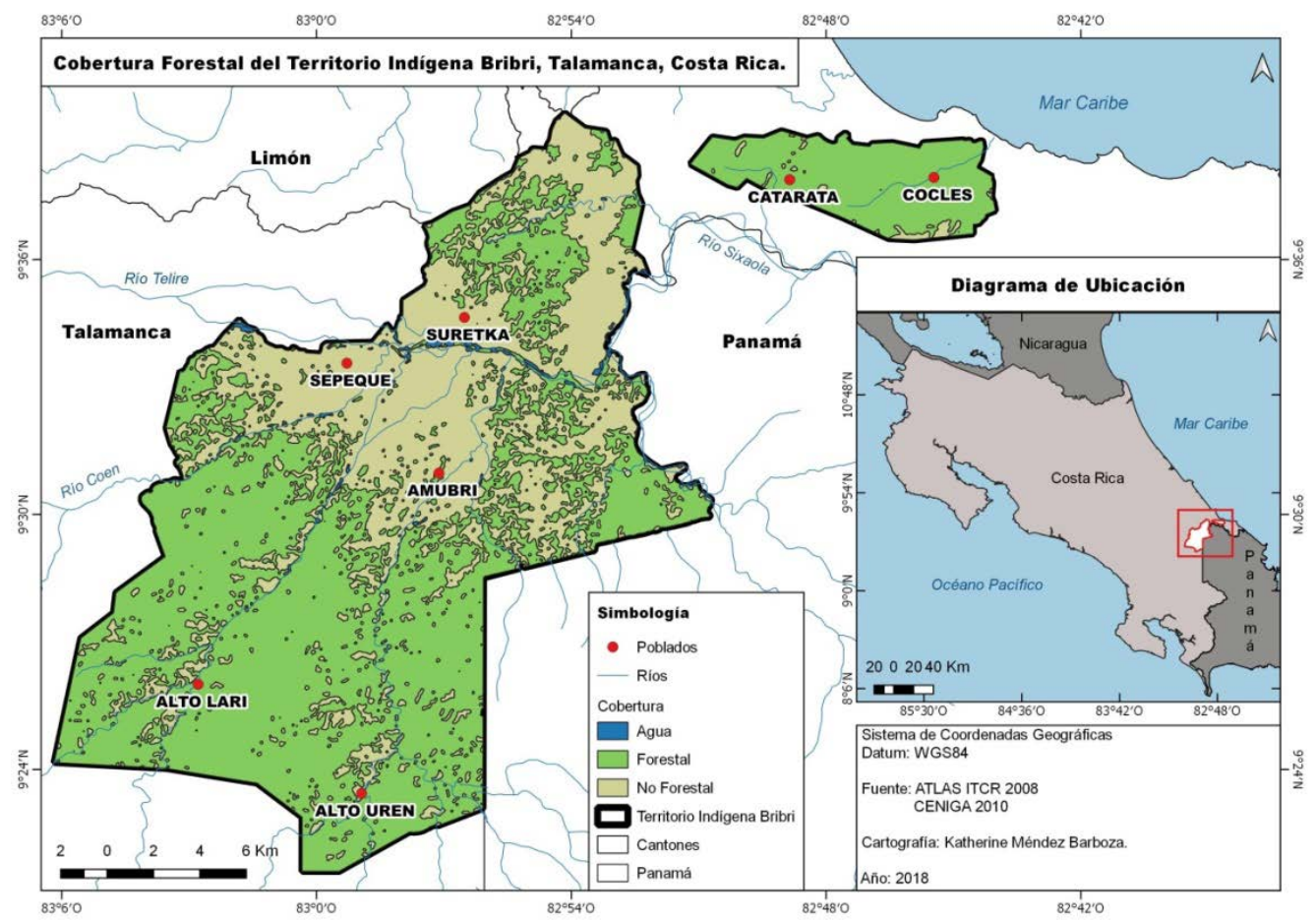

Source: By Authors, based on Atlas ITCR, 2008; CENIGA, 2010.

The Indigenous Development Association (ADI, associations created from the indigenous law in 1977 and its regulations, constitute local governments validated by the State) politically represents the territory. A Bribri community leader (personal communication, 2015), points out that there are currently three organizational dimensions within the Bribri community: traditional authorities, ADI, and community organizations. In their experience, the ADI consults with the other two to make decisions, but there are external questions about the substitution of traditional political organization practices. Parallel to the ADI, the Bribri-Cabécar Indigenous Network (RIBCA) operates, which groups together the eight indigenous territories of the Costa Rican Atlantic zone.

In 2011, based on the logic of representativity, a consulting process for REDD+ was established, through a proposal of ADI, RIBCA, and ACOMUITA (Association of Indigenous Women of Talamanca, a non-regional organization that assumes the representation of women for the REDD+ process). The FONAFIFO directive lead the process, with the participation of 19 indigenous leaders (ADITBRI et al 2012; FONDO NACIONAL DE FINANCIAMIENTO FORESTAL 2013).

In 2014, RIBCA claimed the participation of ADI in the negotiations related to 
REDD + , considering Article 2 of the Indigenous Law and 4 of its regulations where the Associations of Indigenous Development were named as the local government (BAKER, 2014). Members of this local government were set to be elected in territorial assemblies (BAKER, 2014).

The plan's design was cut short by a presidential directive on March $16^{\text {th }}$, and a process for developing a free and informed consultation in concordance with the ILO Convention 169 took place (the "General Consultation Mechanism for Indigenous people" was approved by Executive Decree 40932 on March 6, 2018). Thus, the Costa Rican government presented itself before indigenous communities as being respectful of national and international law pertaining to indigenous rights.

In spite of consent from formal organizations, legitimized by the state, there are other groups within the communities that categorically reject the implementation of the REDD + Project in their territories. Making use of legal pathways and mass meetings, they showed their discontent and sought to reject the mechanism (MENDEZ Y CAMBRONERO, S/f; TELAR COMUNICACIONES, 2014). In this sense, the meeting of representatives of the Ministry of Environment and Energy with the community in the Bribri territory was emblematic. The community spokespeople emphasized the absence of indigenous consultation and stated that only two women of the community participated as representatives and that they were not legal: "They took the authority upon themselves to speak for the Talamaqean people" ((MENDEZ Y CAMBRONERO, S/f; TELAR COMUNICACIONES, 2014) In response, the minister was presented as part of "a new government, a government that is barely 112 days old...that does not want to impose projects," a message seeking credibility through positive self-representation. The state representative, in turn, distanced himself from a possible conflict of interests on behalf of the government for approving REDD + , taking an altruistic stance by recommending the mechanism as economic opportunity for the community.

\section{Processes of de/territorialization of the Bribri forests}

The following section examines the effects and responses of Bribri organizations and their allies to the process of REDD + territorialization upon their forests in three modes where these socioterritorial relations are disputed: governing, knowing, and producing.

\section{Modes of governing: the relation between policies and the political}

In order to understand the controversy around climate change, it is necessary to differentiate policy from politics. Policy refers to the group of actions or initiatives, whose progressive institutionalization generates decision-making mechanisms when faced with phenomena (agreements, norms, regulations, etc.). The political is the contention for power between different agents in social arenas. We link to global, national, and local spaces in order to appropriate those mechanisms and "represent" what constitutes the social within the phenomenon. In this sense, the social of climate change is not given but is a controversial field composed of its forms of representations and modes of associativity 


\section{(BLANCO, 2016).}

In the case of REDD+, the policies are clearly mediated by the agreements on climate change initiated in 1994 with CMNUCC and in 1997 with PK. From there, international institutions and agencies were generated that were replicated on a national level in each country. Costa Rica, however, is a particular case since the public policies on environment were developed at a national or local level before or parallel to international agreements through an early process of institutionalization.

In the global arena, as stated by Ulloa (2011), the main international actors were the governments of developed countries that assisted the technical process of preparation for REDD+ and finance said process, as well as multilateral institutions interested in global climate change actions such as UN-REDD, FCPF, CMNUUC, World Bank, etc. Surrounding REDD + are also stances and associations related to the rights of indigenous peoples and the scope carbon bonds may have for sustaining industrialized countries' GHG emission mitigation commitments.

The experience of the institutionalized and executed PES in Costa Rica suggested that the execution of REDD+ would be quicker in this country. However, since 2007, new norms, entities, and economic investment has been generated within MINAE and FONAFIFO to develop REDD+, without settling on the mechanism.

Costa Rica continues to consult with indigenous territories, where policies to accommodate these communities' own requirements, particularly in relation to sustainable development of forests continues. In this sense, REDD + pushes the country towards the construction of new policies that visibilizes it but the actions taken encounter difficulties in the political.

By concentrating on certain transnational actors surrounding REDD +, a climate eco-governmentality is consolidated (ULLOA, 2011, 2013), prioritizing a rationale of nature fragmentation in market goods (carbon sinks) and an economic logic of payment for conservation, which was already occurring in Costa Rica and had national financing and regulation.

At the international level, social actors emerged with an opposing view to the establishment of REDD+ in indigenous territory, in many cases with a sort of resistance to intend to territorialize the technical-political discourse and practices associated with climate change (DAM, 2011; MOVIMIENTO MUNDIAL POR LOS BOSQUES TROPICALES, 2015). Some initiatives are promoted by the Coordinator of Indigenous Associations of the Amazon Basin (COICA in Spanish), with the support of the WWF, the Interethnic Association of the Peruvian Jungle (AIDESEP in Spanish), and the IDB.

On the other hand, the International Forum for Indigenous People on Climate Change (IIFPCC), demanded that SBSTA grant indigenous communities a more effective participation and respect for traditional forms of knowledge in REDD+ monitoring systems as well as benefits not related to $\mathrm{CO}_{2}$ or non- market benefits. In this sense, COP 21 Paris-2015 opened the possibility of generating policies with an alternative focus to REDD+, such as mitigation and adaptation for the integrated and sustainable management of forests, where strategies not based on the market may be implemented 
(CIRONE, 2016).

At the local level, members of the Bribri tribe gathered in the organization Talamanca for the Life of Earth, with the support of NGOs such as COECOCEIBA, and groups associated with Costa Rican universities such as the Kioskos Socioambientales, lead a movement against REDD+ in indigenous territories, mainly visible since 2014. While these organizations do not assume representation of the peoples, they do accompany detractors of the mechanism in creating spaces for them to voice their concerns.

FONAFIFO sought to negotiate and incorporate the participation of the IDA through participative and inclusive methodologies that considered the cosmovision of indigenous peoples. The preparation phase, specifically the REDD+ pre-consultation proposed by the IDA, RBCA, and ACOMUITA, as an example of the political, also incorporated the economic component, through the payment of travel allowances to cultural mediators (BAKER, 2014).

In the case of funding perceived by the IDA through the PES, there were questions as to its use as well as the prerogatives that would develop by belonging to the Directive Board of the Association that administers them. In this same vein, there were questions about the course they had taken since some community members, such as Baudillo Selles, of Cachabli, Talamanca, considered that the community does not receive benefits, specifically that "it has not satisfied people's most important needs, such as the road and other things" (ERA VERDE, 2014).

These actions indicated ongoing mercantilization, not only of nature, but also of participation and other forms of traditional governance. As stated by Ulloa, the strategies for facing Climate Change are conceived as "an economic opportunity to generate social benefits" (ULLOA, 2011).

On the other hand, the Bribri people doubt the representativity of their own community members in these processes, as expressed by Leonardo Buitrago, of the Bribri people and the Talamanca for Life on Earth organization, when stating that AID is a structure of the government of the Republic (ERA VERDE, 2013).

This stance contrasts with FONAFIFO, which signed the PES conventions with AID, since, according to Jorge Rodríguez, director of that institution "we sign with the registered owners of the property and in this case, it is AID's" (ERA VERDE 2013). This reopens the discussion on how AID as an organization imposed by the state and its implication of governance in the territories.

Another critique on the participation of AID on behalf of the indigenous organizations that was extrapolated from the REDD+ discussion, was that the right to previous, free, and informed consultation was not respected since it had a direct effect on territorial use by restricting hunting, tree felling, and plant extraction (CARAVANA CLIMATICA, 2014). Regarding this, RIBCA indicated that the PES have never affected traditional uses or indigenous medicine of the territory; on the contrary, it is has served to protect natural resources from internal abuses and mining interests (RED INDIGENA BRIBRI Y CABÉCAR, 2014). 
The strategy implemented by some members of the Bribri people rejecting REDD+ has consisted of gathering and divulging information, as well as generating pressure on AID to oppose it; pressure that was made concrete on July 1, 2016, when a document signed by 400 people declaring the "Talamanca-Bribri Territory Free from REDD+" was delivered to ADITIBRI (MENDEZ Y CAMBRONERO, no date).

\section{Modes of knowing: epistemological disagreements}

In the Bribri cosmovision, conservation of the jungle is integrated to their lives and daily practices. Most of the country's forest cover and unextracted or commercialized mineral resources are maintained as a consequence of the interrelation and protection of the Bribri upon the territory.

According to the Bribri people, there is an interdependence between the human being and nature that grants all their needs: food, shelter, medicine, and this is reciprocated with respect, which represents part of the holistic vision of the conservation concept.

This ontological view is far from the approach of the REDD + strategy which, based on the precepts of ecological modernization, implies assuming an ontological separation between society and nature, in order to then establish mechanisms of appropriation, exclusion and/or access to the ecosystems goods and services. Conservation then becomes merchandise, "the result of a neoliberal view of nature" (ULLOA 2013).

On the contrary, according to Selles, to a member of the Bribri community, "money is not necessary, nor are imposed laws for us to preserve them. They are laws written in our hearts, given by Sibö [God]" (ERA VERDE, 2014).

With the creation of the Domestic Carbon Market in Costa Rica in November 2013, the possibility of trading Costa Rican Compensation Units (CCU) in the national stock market was stipulated, marking the liberalization of the market, eliminating FONAFIFO's monopoly on the management of these units. The transition of the Decree of Rules for the Regulations and Operation of the Domestic Carbon Market maintained FONAFIFO as the entity in charge of compensation processes, until the DCM was implemented. In this manner, eco-systemic services were inserted on a broader business horizon for PES beneficiaries.

At least two forms of approachment and relationship with nature are confronted in a disputed space. A space full of history and convivial relations between human, nonhumans, and more than humans, whose resistance is directly linked to the possibility of sustaining a unified territorial and spiritual existence.

In the case of REDD+, the SUBSTA is responsible for giving a technical recommendation from a western epistemological stance, in other words, reassessing expert knowledge without taking local knowledge into account, particularly that of indigenous peoples who have preserved their jungle territories for years. They also create a series of cooperative processes for the implementation of programs in the REDD+ preparation stage, which includes international agencies such as ODA, GEF, IBDR, and FIP among others. 
The Bribri identify knowledge related to the forest that is available to community members. In the case of medicine, the connection to the spiritual world depends on the free use of and access to the jungles: "privatizing the forest to us is like taking the pharmacy away from a hospital" (ERA VERDE, 2014).

The use of this "pharmacy" requires the development of knowledge and collaboration with the spiritual world, which, among the Bribri is assumed by the Awá (traditional indigenous doctor) since they know the language of the plant world (ERA VERDE, 2014).

The general public is unaware of the knowledge of the Bribri people, but community activists highlight it in order to face these new forms of valuing their jungles and as a discursive strategy for awareness.

\section{Means of producing}

The processes of territorialization/deterritorialization can be clearly found in the REDD + execution process in Costa Rica related to the indigenous means of production.

First, there is evidence of corresponding practices and behaviour with mitigation mechanisms through reduction of deforestation and forest conservation, stipulated in the processes of preparation for payment for carbon associated with REDD+.

In this same manner, the imaginary of poor vulnerable indigenous peoples, where the REDD+ are instruments for reaching millennium development aims is created: "As to the multipurpose character of the REDD+ incentives, there is no doubt that the reduction of poverty in most communities and indigenous territories must be a priority" (UN-REDD PROGRAM, 2012).

According to an interview with a FONAFIFO consultor (Personal communication, 2014), in the productive culture of indigenous people, forest conservation is linked to practices associated with the use and forms of cultivation that are inserted in direct association with the forest. A sikua (non-indigenous) does not identify cultivated land because it is an integrated part of the forest landscape. There is no division between production zones for consumption and nature as a carbon sink. In this same manner, domestic animals roam free around their homes. They also hunt; however, there are complaints due to government restrictions on the hunting of wild animals (MENDEZ, 2012). Other traditional practices associated with the cosmovision are related to collaborative activities that have been displaced by mercantile practices, such as the inflow of currency in the territory substituting change of hands or barter, especially work for work (MENDEZ, 2012).

REDD + is yet another element contributing to the introduction of currency in the Bribri economy, added to the impossibility of making use of the forests for their reproduction activities, as confirmed by Jorge Rodríguez, director of FONAFIFO, stating that one of the requisites for participation is that "there be no exploitation" that may endanger the forest health (ERA VERDE, 2013).

This limitation represents a tradeoff of "goods" valued unequally, as well as opposing relations with the forest and ways of conservation. Conservation is circumstantial to the 
Bribri's means of production and, as stated by Ornilio Reyes, it is a way of coexistence with the forest (ERA VERDE, 2014).

While the REDD+ proposal may have antagonists, among the governmental and indigenous world, there is a clear need for information to measure the programs implications, especially in reference to the use of the territory for maintaining their productive practices. This is a demand of the groups opposing REDD+ that see their ways of life at risk.

\section{Conclusions}

This case study analyzed documents about REDD + in relation to the Bribri territory in Costa Rica produced on a local, national, and multilateral level in order to learn about the effects that the intent of implementing this mechanism has generated in their territory. The conclusions outlined below are not intended to be generalized to other Costa Rican territories or those of other latitudes since every locality consists of particular contexts, practices, and discourses. However, in addition to the inherent documental value, some of these results may contribute to understanding processes of implementation of the REDD + in other territories, especially when first conceived, not from national interests, but from a perspective of territorial sovereignty of original peoples.

We identify the effects on the Bribri's way of life, in the preparation stage of the REDD + mechanism, discerning new conflicts among communities where it is being implemented since it responds to different ways of governing, knowing, producing, and definitely inhabiting the territory.

As to forms of governance, there are contradictions between discourse and state practices. Since the ratification of the ILO Convention 169, there is a commitment to respect the autonomy of indigenous peoples, but in practice, organizations established by an Indigenous Law from 1977, that has nothing to do with these people's own forms of governance, continues to be legitimized.

As seen by the stances of government and community actors, the discrepancies in the quest for territorializing REDD+ are established by possible events: i) destabilization of the relative homogeneity of indigenous communities due to the generation or deepening of internal divisions within; ii) doubts about the PES system, which although viewed with approval by the rest of the country, still raises questions about the administration of resources and the representativity of organizations that received them; and iii) weakening of the Bribri autonomy through these consulting processes since they endanger decisionmaking representativity, where the people's cosmovision, practices, and knowledge are recognized and respected. This scene could change with the "General Consulting Mechanism of Indigenous Peoples," which began in March 2018 but goes beyond the period of this research's analysis.

The relational autonomy of these peoples is demonstrated. They are regulated by national and international laws that grant and "protect" their rights while they are also inserted into a world of meanings and representations that are not part of their cosmovi- 
sion; however, they have operated as mechanisms of struggle and resistance in the face of pressure on their territory.

The implementation of REDD+ alters the relation of interdependence that the Bribri people have established with nature, incorporating external market dynamics that have implications in their means of knowledge and ways of life, and also form a dependance on the stability of the carbon markets. Techno-scientific knowledge takes center stage, pointing towards what must be done at a local level for forest conservation, and how developed countries must help, without any "self-criticism" on the cause of deforestation and the models that cause it.

The discrepancies surrounding the implementation of REDD+ in indigenous territory stems from the recognition of different rationales. The valuation of nature by the Bribri people converges with western ideas of conservation, reflected in the policies of international organisms, but itself in the form and substance of the why and how to conserve it.

Means of production create representations of indigenous peoples as vulnerable groups from a deteritorrialized viewpoint that does not take into consideration that, in the particular case of Costa Rica, the forests of indigenous territories are well preserved.

Limiting the use of territories for traditional activities of indigenous peoples affects the means of production by displacing consumption towards the market and requiring the use of a national currency.

In the Bribri's socio-materiality, nature, spirit, production, and humanity are not disassociated from the territorial unit that REDD+ separates conceptually in forests and communities.

In synthesis, controversies are identified in the discourses of national and international institutions interested in implementing REDD+ with this study. The processes of de/re/territorialization of the mechanism in this study are legitimized by discursive strategies where the good will of developing countries to contribute to the mitigation of climate change dominates all while committing economic support to developing countries. On the other hand, developing countries and particularly indigenous peoples are constructed as poor, vulnerable, and destroyers of forest, ignorant of technical language and subjects of control.

The findings give the Bribri people unforeseen variables that they may put into play in negotiation processes. In this same manner, there must be broader research that gathers practices and perceptions of social actors through qualitative field work, overcoming the limitations of a predominantly documental corpus.

Finally, by way of recommendation, it is considered that mechanisms such as REDD + may be implemented, but under the logic and practices that indigenous peoples have about conservation and care for nature, respecting their autonomy for the integration of modes of government, production, and knowledge. 


\section{Acknowledgments}

This work was partially supported by the Climate and Resilience Research Center, FONDAP Program $N^{\circ} 15110009$ funded by the National Agency of Research and Development of Chile.

\section{References}

ADITIBRI et al. Plan de consulta indígena en el proceso de elaboración de la estrategia nacional de REDD+ DE Costa Rica. 2012. Available in: http://www.bankinformationcenter.org/ wp-content/uploads/2014/02/Plan-de-consulta-nacional-indigena-sobre-REDD+.pdf.

ANDERSON, B; MCFARLANE, C. Assemblage and geography. Area, V. 43, n. 2, p. 124-127, 2011.

BAKER, R. Impulsando la Participación de los Pueblos Indígenas en REDD+. La inclusión temprana y la consulta en Costa Rica [internet]. 2014. Available in: http://www.bankinformationcenter.org/wp-content/uploads/2014/03/EstudioDeCaso-ParticipacionIndigenaREDDCostaRica-Espanol-Marzo2014-VersionWeb.pdf. Accessed: 6 oct 2017.

BLANCO, G. Abriendo la caja negra del cambio climático: claves para comprender su trayectoria política en América Latina. En: LAMPIS, A (Ed). Cambio Ambiental Global, Estado y Valor Público: La Cuestión Socio-Ecológica en América Latina, entre Justicia Ambiental y "Legítima” Depredación. Bogotá: Universidad Nacional de Colombia, Centro de Estudios Sociales (CES), Consejo Latinoamericano de Ciencias Sociales, Pontificia Universidad Católica de Perú, p. 45-66, 2016.

CARAVANA CLIMÁTICA. Entrevista a Leonardo Buitrago [audio]. San José, Costa Rica, 2014.

CIRONE, M. Avances de REDD+ en la COP21 de París [internet]. Argentina: FLACSO, 2016. Available in: http://www.ambienteycomercio.org/wp-content/uploads/2016/05/Cirone-Galarza-REDD-en-el-Acuerdo-de-Par\%C3\%ADs.pdf. Accessed: 28 ene 2018.

CULAS, R. REDD and forest transition: Tunneling through the environmental Kuznets curve. Ecological Economics [internet]. V. 79, p. 44-51, 2012. Available in: https://doi.org/10.1016/j. ecolecon.2012.04.015. Accessed: 6 oct 2017.

DAM, C. Territorios indígenas y REDD en América Latina ¿Oportunidad o amenaza? En: PETKOBA, E, et al. (Ed.). Gobernanza forestal y REDD+. Desafíos para las políticas y mercados en América Latina [internet]. Indonesia: CIFOR, p. 253-270, 2011. Available in: http://www. cifor.org/publications/pdf_files/Books/BPetkova1101.pdf. Accessed en: 6 oct 2017.

DE LANDA. M. A new philosophy of society: Assemblage theory and social complexity. Lon- 
don. New York: Continuum, 2006.

. Assemblage theory. Edinburgh University Press, 2016.

DIRECCIÓN DE CAMBIO CLIMÁTICO COSTA RICA. Mercados de carbono [internet]. Available in: http://www.cambioclimaticocr.com/2012-05-22-19-47-24/programas/mercados-de-carbono. Accessed: 6 feb 2018.

ERA VERDE. REDD+ una visión crítica [video]. San José, Costa Rica: Universidad de Costa Rica; 2013. Available in: https://www.youtube.com/watch?v=FbxGwQsbcOU\&t=36s.

¿Es la estrategia REDD un instrumento válido para proteger nuestros bosques? [video]. San José, Costa Rica, Universidad de Costa Rica, 2014. Available in: https://www.youtube. $\mathrm{com} /$ watch? $=$ CCS8wp_Pv8Q.

FONAFIFO. Proyecto Bosque Vivo - Territorio Indígena Bribri, Talamanca [internet]. Costa Rica, 2013. Available in: http://www.fonafifo.go.cr/inversiones/csa\%20 bosque\%20vivo/BV_Bribri.pdf. Accessed: 5 mar 2015.

. Estrategia REDD+ Costa Rica [internet]. Costa Rica, 2014 Available in: http://www. fonafifo.go.cr/proyectos/redd.html. Accessed: 5 feb 2018.

. Hectáreas PSA, árboles SAF y montos contratados en los territorios indígenas de Costa Rica, del Programa de Pago por Servicios Ambientales, período 1997-2018 [Internet]. 2019a. Available in: http://www.fonafifo.go.cr/es/servicios/estadisticas-de-psa/

. Resumen de contratos por tipo de beneficiario del PSA, período 1997 - 2018 [Internet]. 2019b. Available in: http://www.fonafifo.go.cr/es/servicios/estadisticas-de-psa/

FONDO DEL PRIMER CANJE DE DEUDA POR NATURALEZA EE.UU-C.R. Bosques para todos. Boletín 5. San José Costa Rica, agosto, 2013.

FOREST CARBON PARTNERSHIP FACILITY [internet]. 2017. Available in: https://www. forestcarbonpartnership.org/knowledge-and-resources. Accessed: 4 feb 2018.

HOUGHTON, R. Tropical deforestation as a source of greenhouse gas emissions. In: MOUTINHO, P., SCHWARTZMAN, S. (Ed.). Tropical Deforestation and Climate Change. Belem-Pará, Brazil, Instituto de Pesquisa Ambiental da Amazônia, p.13-21, 2005.

INSTITUTO NACIONAL DE ESTADÍSTICA Y CENSO. X Censo Nacional de Población y VI de Vivienda: Territorios indígenas principales indicadores demográficos y socioeconómicos. San José, Costa Rica, 2013.

MAHANTY, S. SUICH, H. TACCONI, L. Access and benefits in payments for environmental services and implications for REDD+: Lessons from seven PES schemes. Land Use Policy. V. 31, p. 38-47, 2013.

MENDEZ, Z. (Ed.). REDD+ y el negocio de los bosques: peligros para pueblos indígenas. San 
José, Costa Rica, Universidad de Costa Rica, Vicerrectoría de Acción Social, 2014a.

MENDEZ, Z. Comprensión sobre procesos de resistencias indígenas: el caso de recuperación de saberes con jóvenes bribris en Alta Talamanca [tesis]. Universidad de Costa Rica; 2014b.

MÉNDEZ, Z. CAMBRONERO, A. Versión extensa del conflicto [internet]. S/f Available in: http://www.feconcr.org/doc/CronologiaREDD\%2BCR.pdf. Accessed: 6 feb 2018.

MÉNDEZ, Z. RODRÍGUEZ, M. Ditsowo Tsirik: el camino de la semilla [video]. San José, Costa Rica, Universidad de Costa Rica, 2012. Available in: https:/www.youtube.com/ watch? $=$ xpylOMbOHHo.

MILLA, V. REDD+ y territorios indígenas en Costa Rica: oportunidades de desarrollo comunal desde la perspectiva del manejo de los recursos forestales. Turrialba, Costa Rica, Centro Agronómico Tropical de Investigación y Enseñanza, 2011.

MOLITOR, M. Sobre la Hermenéutica Colectiva. Revista Austral de Ciencias Sociales. V. 3, p. 3-14, 2001. Available in: http://mingaonline.uach.cl/pdf/racs/n5/art01.pdf.

MOVIMIENTO MUNDIAL POR LOS BOSQUES TROPICALES. REDD: una colección de conflictos, contradicciones y mentiras [internet]. Montevideo, Uruguay, World Rainforest Movement, 2015. Available in: https://wrm.org.uy/es/files/2014/12/REDD-Coleccion_de_conflictos_contradicciones_y_mentiras_expandido.pdf. Accessed: 6 feb 2018.

PETKOBA, E. LARSON, A. Riesgos y Oportunidades. Una introducción a la gobernanza forestal, las comunidades y REDD+ en América Latina. En: PETKOBA, E, et al. (Ed.). Gobernanza forestal y REDD+. Desafíos para las políticas y mercados en América Latina [internet]. Indonesia: CIFOR, p. 9-31, 2011. Available in: http://www.cifor.org/publications/pdf_files/Books/ BPetkova1101.pdf. Accessed: 6 oct 2017.

PROGRAMA ONU-REDD. La tenencia de los territorios indígenas y REDD+ como un incentivo de manejo forestal: el caso de los países mesoamericanos [internet]. Suiza, 2012. Available in: http://www.fao.org/3/a-i2875s.pdf Accessed: 8 feb 2018.

RED INDÍGENA BRIBRI Y CABÉCAR. Pronunciamiento de la Red Indígena Bribri y Cabécar con relación a REDD+. Limón, Costa Rica, 2014.

TELAR COMUNICACIONES. Estas tierras no tienen precio [video]. San José, Costa Rica, Kioskos Socioambientales, 2014. Available in: https://www.youtube.com/watch?v=XElIGxm ohk.

UllOA, A. Políticas Globales del Cambio Climático: Nuevas geopolíticas del conocimiento y sus efectos en territorios indígenas. Construcciones culturales sobre el clima. En: ULLOA, A. (Ed.). Perspectivas culturales del clima. Bogotá, Colombia, Universidad Nacional de Colombia, p. 55-82, 2011.

. Controlando la naturaleza: ambientalismo transnacional y negociaciones locales en torno al cambio climático en territorios indígenas en Colombia. Revista Iberoamericana. V. XIII, 
n. 49, p. 117-33, 2013.

VAN DIJK, T. Análisis del discurso ideológico. Versión. Estudios de comunicación y política. V.6, p. 15-43, 1996.

WUNDER, S. Revisiting the concept of payments for environmental services. Ecological Economics. V. 117, p. 234-43, 2015. 
Maritza Marín-Herrera

$\square$ maritza.marin@ucr.ac.cr

https://orcid.org/0000-0001-6165-724X
Submitted on: 25/09/2018

Accepted on: 14/10/2020

2021;24e:02312

\section{Heidy Correa-Correa}

$\square$ heidy_correa@yahoo.com

https://orcid.org/0000-0002-8235-1642

\section{Gustavo Blanco-Wells}

ఐgblanco@uach.cl

https://orcid.org/0000-0002-4980-3424

How to cite: MARIN-HERRERA, M.; CORREA-CORREA, H.; BLANCO-WELLS, G. Territorialization of the REDD + strategy in the Bribri Indigenous people Talamanca, of Costa Rica. Ambiente \& Sociedade. São Paulo, v. 24, p. 1-22, 2020. 


\title{
Territorialização da estratégia REDD+ no povo indígena bribri, Talamanca, Costa Rica
}

\author{
Maritza Marín-Herrera \\ Heidy Correa-Correa \\ Gustavo Blanco-Wells
}

São Paulo. Vol. 24, 2021

Artigo Original
Resumo: Neste artigo, são explorados os efeitos nos meios de vida e a avaliação da natureza do povo bribri em Talamanca, Costa Rica, contra a tentativa de implementar REDD + nos seus territórios. Por meio de estudo de caso, análise de discurso e hermenêutica coletiva sobre documentos e entrevistas produzidos por atores sociais internacionais, nacionais e locais, controvérsias manifestas são identificadas através de processos de des/re/territorialização da iniciativa. Esses processos são legitimados por estratégias discursivas tecnocráticas associadas à mitigação das mudanças climáticas, produzidas em espaços multilaterais de negociação e adaptadas pelas instituições nacionais para fins não alinhados aos interesses das comunidades. Conclui-se que a implementação de REDD + em terras indígenas na Costa Rica permite: i) mercantilizar a natureza, a participação e as formas tradicionais de governança; ii) consolidar eco-governabilidade climática centrada fragmentação da natureza; iii) construir representações indígenas vulneráveis e empobrecidas, para justificar a intervenção nos seus territórios.

Palavras-chave: Territorialização; eco-governabilidade Climática, Povos nativos; Pagamentos por Serviços Ambientais.

Como citar: MARIN-HERRERA, M.; CORREA-CORREA, H.; BLANCO-WELLS, G. T Territorialização da estratégia REDD+ no povo indígena bribri, Talamanca, Costa Rica. . Ambiente $\mathbb{\&}$ Sociedade. São Paulo, v. 24, p. 1-22, 2021. 


\title{
Territorialización de la estrategia REDD+ en el pueblo indígena bribri, Talamanca, Costa Rica
}

\author{
Maritza Marín-Herrera \\ Heidy Correa-Correa \\ Gustavo Blanco-Wells
}

São Paulo. Vol. 24, 2021

Artículo original
Resumen: Se exploran los efectos en los modos de vida y valoración de la naturaleza del pueblo indígena bribri en Talamanca, Costa Rica, ante el intento de implementar REDD+ en sus territorios. Mediante estudio de caso, análisis de discurso y hermenéutica colectiva sobre documentos y entrevistas producidos por actores sociales internacionales, nacionales y locales, se identifican controversias manifiestas a través de procesos de des/re/territorialización de la iniciativa. Estos procesos son legitimados por estrategias discursivas tecnocráticas asociadas a la mitigación del cambio climático, producidos en espacios de negociación multilateral, y adaptados por instituciones nacionales a propósitos no alineados con intereses de las comunidades. Se concluye que la implementación de REDD + en Costa Rica posibilita i) mercantilizar la naturaleza, la participación y las formas de gobernanza tradicionales; ii) consolidar una eco-gubernamentalidad climática centrada en la fragmentación de la naturaleza; iii) construir representaciones sobre indígenas vulnerados y empobrecidos, para justificar la intervención en sus territorios.

Palabras-clave: Territorialización; Eco-gubernamentalidad Climática; Pueblos originarios; Pagos por Servicios Ambientales.

Como citar: MARIN-HERRERA, M.; CORREA-CORREA, H.; BLANCO-WELLS, G. Territorialización de la estrategia REDD+ en el pueblo indígena bribri, Talamanca, Costa Rica. . Ambiente $\&$ Sociedade. São Paulo, v. 24, p. 1-22, 2021. 